\title{
Human Security in World Affairs: A Pedagogical, Multi- disciplinary Approach
}

\author{
Published: 2 April 2014
}

Keywords: human security; individual and group responsibility; multi-disciplinary approach; pedagogical

\author{
Human Security in World Affairs: Problems \\ and Opportunities \\ Alexander K. Lautensach, Sabina W. Lautensach \\ (eds.) \\ Caesarpress: 2013 \\ 504 pp.; ISBN: 978-3-902890-00-9
}

The end of the Cold War and the ever increasing interconnectivity in our globalised world have resulted in much debate in academia, in politics, and elsewhere about the progress of human security. The debate is no longer limited to the fundamentals of human biological and physiological needs such as air, food and shelter, or to basic safety issues such as protection, security, law and order, and stability. Over the last decade, proponents of the human security thesis have aimed for an even wider conceptualisation of what this term is supposed to mean. The idea of human security is now seen to relate not just to individuals, groups or states but to entire regions, and even globally. It refers not only to the human condition of individual or group responsibility, but to the allencompassing social and political environment that make it possible for humanity to survive and to have a life at least mostly free from want and fear.

Alexander and Sabina Lautensach (editors) write that their book is primarily intended for students and for teaching, and that a pedagogical approach was prioritised rather than a reproduction in the standard format of an academic monograph (p. XVII). Throughout, they aim for a diverse, multi-/trans-disciplinary approach in term of content and presentation from contributors, with potential student outcomes focused on flexibility and a broad spectrum knowledge and understanding of human security. To these ends they have been very successful. This hefty tome, almost encyclopaedic in its scope and depth, needs to be approached by students in a certain way. That is, students will benefit from some directed guidance regarding approach and methodology in order to successfully navigate through the many detailed concepts, theories and practicalities contained in the book. This is clearly provided in the preface where the editors spend quite some time outlining the rationale of the book in a simple and easy to understand way that will be particularly useful for students and other engaged readers. The Synopsis and list of Learning Outcomes \& Big Ideas at the beginning of each chapter, as well as the Summary Points and Extra Activities \& Further Research at the end are further useful tools to consolidate learning and direct the student to other associated research.

The book has two broadly overlapping sections. The first part of these, Chapters 1 to 13, presents, analyses and discusses problems and challenges, while the second part, Chapters 14 to 19 , is more focused on possible solutions. The overlap is less so in the former and more so in the latter. A distinction in approaches between the two sections is not immediately obvious but it is there, and the book has a logical progression from general to more specific throughout.

The book begins with a comprehensive Introduction by the editors that could almost have been a separate chapter presented with all the others. The introduction provides a useful context for the discussion 
of human security, but some of this could have been incorporated into Chapter 2, "Why Human Security Needs our Attention", which is co-authored by one of the editors. This would leave room in the introduction for a useful and more detailed description of what the long list of chapters in the book are about. The chapter descriptions in the introduction are sometimes just one or two line statements, for example, "The complex challenges of international development aid are discussed in Chapter 13" (p. XXXIV) and "Chapter 17 addresses the reduction of armed conflict, and in Chapter 18 strategies for peace building are discussed" (p. XXXV). Each chapter in the content area does have a solid synopsis and introduction, but it would be useful for readers to have a condensed version of what each chapter-or perhaps couple of chapters-contains.

A particular challenge for proponents of the human security ethos is to focus analysis and argument in such a way that does not overly dilute its central thesis. There is a danger of the discourse ending up with human security being related to everything, everywhere, all the time and about anything even remotely associated with the human condition and experience. The book does tackle a very broad range of human security related issues, from religion, war, terrorism, various political orders, and globalization through to environmental decay, resource scarcity, a 'war against nature', governance at local, regional and global levels, social constructivism, health...the list goes on. The editors frequently remind the reader early in the book that their approach and the author's contributions are wide-ranging and deliberately multi-/ trans-disciplinary, something which they certainly achieved. Throughout the book, the editors have managed to very successfully bring together this large collection of disparate approaches to the subject of human security in a meaningful way.

Chapters 1 to 4 help to contextualise the notion of human security. Chapter 1, "Human Security Foundation Documents and Related Sources" would perhaps be better placed after Chapter 2, "Why Human Security Needs our Attention". For readers to be convinced that human security is important they need to know why it is important in the first place. The importance of human security is concisely and comprehensively articulated in Chapter 2. Chapter 4, "Threats to Human Security-An Overview" is the stand-out chapter in this part of the book, providing a succinct outline of human security. Chapters 5 through to Chapter 13 then provide the reader with a broad swathe of useful topics such as security challenges facing individuals and groups within states; human security and international law; environment and access to resources concerns; transnational crime; governance and ideological imperatives. Most of the chapters integrate very well with the central theme of the book, although Chapter 8 "Globalization Processes" would benefit from some clearer linkage to the core human security thesis.

Chapters 14 through to Chapter 20 present further challenges to human security and incorporate many interesting approaches, outcomes and possible solutions to the topics presented. This is where the book stamps its authority in human security analysis and argument, and it is what the engaged reader will find the most interesting and enjoyable to read. This is not to say that the earlier part of the book is lacking in some way, but the second half has a more directed attention to a bottom-line approach regarding options and possible solutions.

The greatest strength of the book is in its extensive critical analysis and discussion in each of the chapters. The book is very ambitious in its scope and depth as it focuses on a wide range of theoretical, empirical and practical challenges that the human security paradigm poses. While there could be some minor rearrangement of a couple of the early chapters and a little more directed chapter information in the introduction, these observations do not detract from the very detailed and useful content of the book as a whole. This is currently the best generalist text book on the market regarding human security. The scope, breath and depth of the topics covered in the book, and the way that the editors have managed the hugely difficult task of organising the chapters into a coherent and meaningful manner, make this an outstanding text book for university undergraduates and post-graduate learners. While the editors say that this is the reading audience the book is aimed at, I consider that the book will also have a strong appeal for a much wider readership outside academia.

\section{John Janzekovic}

Lectures in Politics, International Relations, International Justice and Human rights, University of the Sunshine Coast, Maroochydore, Queensland, Australia; E-Mail: jjanzek1@usc.edu.au 